\title{
Rancang Bangun Sistem Informasi Penggajian Pegawai Berbasis Web di Madrasah Ibtidaiyah Nurul Huda Kota Tangerang
}

\author{
Rohmat Taufiq ${ }^{1}$, Risma Rohmatul Ummah ${ }^{2}$, Irfan Nasrullah ${ }^{3}$ dan Angga Aditya Permana \\ 1,2,3,4 Teknik Informatika, Fakultas Teknik Universitas Muhammadiyah Tangerang, Jl. Perintis \\ Kemerdekaan I No. 33 Cikokol Tangerang, Indonesia, 15117 \\ e-mail: 'rohmat.taufiq@umt.ac.id; ${ }^{2}$ rismarohmatul.ummah19@gmail.com; \\ 3pejuang2000@gmail.com; ${ }^{4}$ anggaumt@gmail.com
}

Submitted Date: January $5^{\text {th }}, 2020$

Revised Date: January $7^{\text {th }}, 2020$
Reviewed Date: January $5^{\text {th }}, 2020$

Accepted Date: January $9^{\text {th }}, 2020$

\begin{abstract}
Madrasah Ibtidaiyah Nurul Huda Kota Tangerang is one of the private schools, but data processing payroll in this schooll was still unintegrated. The ongoing payroll system was still in use of a manual system. The results of this were many obstacles faced by the school in the production of materials such as in payroll contracts, payroll calculations, payroll slips, and drawing up payroll reports. Also, the information presentation was less fast, inexact, inaccurate because current media transmission information consists of purely physical documents. The research method used waterfall method. Waterfall is a model of its development process for the coverage of a system, sequential or linear. The research steps were divided into: analysis, design, coding, testing and maintenance. The system would then be built using synthetic programming language PHP and Mysql as a database. The web-based employee payroll information system was intended to provide advantages in payroll data processing such as payroll process, payroll calculations, payroll slips, and payroll reports, so that manual jobs could be much easier and computerized. The result was derived from this research was development of the web-based employee payroll information system.
\end{abstract}

Key Word: Information System, employee payroll, Waterfall, Web.

\begin{abstract}
Abstrak
Madrasah Ibtidaiyah Nurul Huda Kota Tangerang merupakan salah satu sekolah swasta yang proses pengolahan data panggajiannya masih belum terintegrasi. Sekolah ini masih menggunakan sistem penggajian yang konvensional dilakukan penghitungan secara manual. Akibatnya banyak masalah/kendala yang dihadapi oleh pihak sekolah dalam aktifitas penggajiannya termasuk pada proses penggajian, penghitungan gaji, pembuatan slip gaji, dan pembuatan laporan penggajian. Karena dilakukan secara konvensional dan menggunakan dokumen fisik, maka penyajian informasinya menjadi kurang cepat, kurang tepat dan akurasinya rendah. Pada penelitian ini diusulkan dikembangkan aplikasi penggajian dengan model waterfall karena kebutuhannya sudah jelas dan didefinisikan di awal secara lengkap. Waterfall adalah sebuah model proses pengembangannya dengan sistem pengerjaan secara berurutan dari awal sampai akhir secara linear. Tahap penelitian ini terbagi dalam beberapa langkah di antaranya analysis, design, coding, testing, dan maintenance. Sistem penggajian diusulkan menggunakan pemrograman PHP dan database MySQL berbasis web agar mudah dilakukan perawatan (maintenance). Sistem informasi penggajian pegawai berbasis web yang dikembangkan ditujukan untuk memberikan kemudahan dalam pengolahan data penggajian seperti peroses penggajian, penghitungan gaji, pembuatan slip gaji, dan pembuatan laporan penggajian, sehingga aktifitas penggajian yang sebelumnya dilakukan secara konvensional dapat lebih mudah, cepat, dan akurat. Hasil pengembangan sistem penggajian dapat melakukan efisiensi dan meningkatkan kinerja operasional.
\end{abstract}

Kata Kunci: Sistem Informasi, Penggajian Pegawai, Waterfall, Web. 


\section{Pendahuluan}

Dalam era revolusi industry 4.0 seperti sekarang ini tidak bisa dipungkiri lagi bahwa teknologi informasi menjadi suatu ala yang luar biasa kemanfaatannya bagi perusahaan untuk memenangkan persaingan. Dengan teknologi informasi yang semakin canggih maka sebuah sistem informasi yang dihasilkan juga akan memiliki kecepatan dan keamanan yang lebih jika dibandingkan dengan sistem informasi tahun-tahun sebelum sekarang ini. Hingga saat ini tidak hanya perusahaan besar yang memanfaatkan teknologi informasi bahkan home industri pun ikut berkecimpung dalam penggunaan teknologi ini. Selain itu, manfaat real yang bisa dinikmati oleh masyarakat luas, saat ini masyarakt bisa melakukan proses jual beli tanpa harus memiliki produk sendiri (drop ship).

Dengan adanya komputer dan jaringannya akan memberikan manfaat bagi seluruh manusia untuk membantu menyelesaikan perkerjaan mereka sesuai dengan bidang masing-masing. Bahkan dalam bidang usaha komputer memiliki peran yang sangat besar dalam proses pendukung pengambilan keputusan. Bahkan, di dunia pendidikan pun komputer menjadi salah satu andalan untuk memproses data-data yang ada di sekolah.

Sekolah Madrasah Ibtidaiyah Nurul Huda Kota Tangerang, adalah lembaga pendidikan yang mempunyai tugas dalam bidang pendidikan berdasarkan asas otonomi dan tugas pembantuan. Madrasah Ibtidaiyah Nurul Huda Kota Tangerang memiliki sebuah sistem informasi tentang penggajian yang saat ini prosedur yang diterapkan pada pengelolahan data penggajian masih secara manual serta sering mengalami kesalahan dalam penggajian pegawai.

Dengan penggunaan komputer di dalam Madrasah Ibtidaiyah akan memberikan efisiensi waktu yang dulunya pekerjaan yang sama dilakukan secara berulang-ulang. Sedangkan dengan menggunakan komputer pengguna tinggal melakukan pencarian dan dicetak (print).

Berdasarkan latar belakang, maka penulis tertarik untuk melakukan penelitian bidang penggajian pada sekolah MI. Nurul Huda Kota Tangerang dengan memilih judul "Rancang Bangun sistem informasi penggajian pegawai berbasis web di MI. Nurul Huda Kota Tangerang”.

\section{Landasan Teori}

Dalam poin ke dua ini akan menjelaskan teori-teori yang digunakan untuk memperkuat penelitian ini, teori tersebut meliputi rancang bangun, sistem informasi, gaji, pegawai yang akan dijelaskan sebagai berikut:

\section{a. Pengertian Rancang Bangun}

Perancangan sistem merupakan suatu aktifitas/proses yang dilakukan untuk menggambarkan bagaimana proses bisnis berjalan dengan membuat diagram seperti use case diagram (Deni dan Nur, 2013). Salah satu proses perancangan atau proses pengembangan sistem yang sudah ada dan banyak diketahui oleh pengembang adalah System Development Life Cycle (SDLC), langkah yang ada dalam SDLC ini terdiri dari 5 bagian yaitu Investigasi, Analisis, Desain, Implementasi dan Pemeliharaan dan Pengkajian (Taufiq, 2018).

\section{b. Pengertian Sistem Informasi}

Kumpulan dari subsistem-subsistem yang terintegrasi dan berkolaborasi dengan tujuan untuk menyelesaikan masalah tertentu menggunakan komputer untuk mengolah data sehingga memberikan nilai tambah serta bermanfaat bagi pengguna disebut sistem informasi (Taufiq, 2013). Sedangkan menurut ahli yang lain sistem informasi adalah sebuah kumpulan komponen-komponen yang mencakup orang, perangkat keras, perangkat lunak, media/jaringan komunikasi dan sumber daya data, yang bekerja dengan cara menghimpun, mengubah dan menyampaikan informasi dalam sebuah organisasi (Indrajani, 2014).

Mengacu dari beberapa definisi di atas maka dapat disimpulkan bahwa sistem informasi merupakan data yang dihimpun lalu diolah sehingga menjadi kumpulan informasi yang memiliki makna penting bagi penerimanya.

\section{c. Definisi Gaji Menurut Para Ahli}

Ada banyak pengertian gaji dari berbagai sisi jika dilihat menurut ahli namun dalam penelitian ini ada dua sumber yang diambil. Yang pertama gaji merupakan sesuatu berupa uang atau yang berkaitan dengan uang dan diberikan kepada pegawai/karyawan sebagai imbalan pekerjaan (Samsudin, 2010). Sedangkan pengertian gaji yang kedua adalah semua yang dibayarkan perusahaan kepada pegawainya. Seorang pimpinan (manajer), para karyawan administrasi, serta karyawan bagian penjualan, umumnya diberikan gaji dari perusahaan dengan jumlah yang tetap. Besaran gaji umumnya dinyatakan dengan nilai gaji per bulan (Tofik, 2010)

\section{d. Definisi Pegawai}

Pegawai merupakan seseorang yang melakukan pekerjaan pada pemberi kerja, baik 
yang statusnya pegawai tetap atau pegawai tidak tetap, dengan berdasarkan perjanjian kerja bersama baik tertulis maupun tidak tertulis, dengan tujuan untuk menyelesaikan/mengerjakan suatu pekerjaan dengan jabatan atau aktifitas tertentu yang ditetapkan oleh pemberi kerja. (Robbins, 2006).

\section{e. Unifield Modeling Language (UML)}

UML (Unified Modeling Language) merupakan notasi pemodelan perangkat lunak yang berparadigma "berorientasi objek". Tujuan pemodelan (modeling) adalah untuk penyederhanakan permasalahan-permasalahan yang kompleks sehingga menjadi lebih mudah untuk dipelajari dan dipahami (Nugroho, 2010).

\section{Metode Pengumpulan Data}

Dalam meteode pengumpulan data yang dilakukan dalam penelitian ini terdiri dari 3 langkah, yaitu studi pustaka, observasi dan wawancara:

\section{Studi Pustaka}

Dalam langkah ini yang dikerjakan adalah pengumpulan data dari dari berbagai sumber termasuk buku, dokumen, dan publikasi dari berbagai sumber. Data yang telah dikumpulkan dijadikan sebagai sumber pengetahuan dan dijadikan landasan teori dalam mengembangkan sistem informasi penggajian pegawai.

\section{Observasi}

Observasi merupakan kegiatan pengamatan langsung pada sistem dan para pengguna sistem yang sedang berjalan. Pada kegiatan ini dilakukan pengamatan dan pencatatan pada sistem penggajian pegawai yang sedang berjalan di MI. Nurul Huda Kota Tangerang.

3. Wawancara

Wawancara yang dilakukan dengan mewawancarai staff bagian keuangan di sekolah MI. Nurul Huda Kota Tangerang untuk mendapatkan data/informasi tentang kekurangan dari sistem yang ada dan kebutuhan-kebutuhan yang diperlukan untuk meningkatkan kinerja operasional.

\section{Analisis dan Implemetasi}

Analisa dan implementasi sistem dilakukan secara bertahap. Tahapan yang dilakukan adalah:

\section{a. Analisis Sistem yang Sedang Berjalan}

Pada tahap awal dilakukan analisa terhadap prosedur dari sistem informasi penggajian pegawai yang ada di MI. Nurul Huda Kota Tangerang.

Analisa yang dilakukan mencakup analisis kebutuhan sistem dan evaluasi terhadap sistem yang digunakan saat ini. Analisis sistem merupakan aktifitas penguraian suatu sistem informasi yang utuh menjadi komponen-komponen yang lebih kecil dengan maksud mengidentifikasi dan mengevaluasi sistem untuk menemukan kekurangan-kekurangan yang ada dan kebutuhankebutuhan pengembangan yang diharapkan sehingga dapat diusulkan perbaikan-perbaikannya.

\section{b. Analisis Sistem yang Diusulkan}

Melihat sistem yang sedang berjalan pada MI Nurul Huda Kota Tangerang saat ini, maka dengan ini dapat disimpulkan beberapa kekurangan dalam prosedur sistem yang sedang berjalan di antaranya adalah:

Tabel 1 Evaluasi Sistem Berjalan

\begin{tabular}{|c|l|l|}
\hline No & \multicolumn{1}{|c|}{ Sistem Lama } & \multicolumn{1}{c|}{ Sistem Baru } \\
\hline 1. & $\begin{array}{l}\text { Pengolahan } \\
\text { penggajian sistem } \\
\text { memerlukan waktu } \\
\text { yang lama }\end{array}$ & $\begin{array}{l}\text { Pengolahan data } \\
\text { mudah karena } \\
\text { dilakukan oleh sistem }\end{array}$ \\
\hline 2. & $\begin{array}{l}\text { Informasi } \\
\text { penggajian yang } \\
\text { dihasilkan masih } \\
\text { mempunyai tingkat } \\
\text { kesalahan yang } \\
\text { cukup tinggi }\end{array}$ & $\begin{array}{l}\text { Sistem yang } \\
\text { diusulkan diharapkan } \\
\text { dapat memberikan } \\
\text { informasi penggajian } \\
\text { yang cepat dan akurat }\end{array}$ \\
\hline 3. & $\begin{array}{l}\text { Penggunaan } \\
\text { kertas, dan alat } \\
\text { tulis lainnya untuk } \\
\text { pencatatan sangat } \\
\text { boros, dan juga } \\
\text { sering terjadi } \\
\text { kehilangan laporan } \\
\text { penggajian. }\end{array}$ & $\begin{array}{l}\text { Dengan sistem } \\
\text { komputerisasi akan } \\
\text { menghemat waktu } \\
\text { dan penggunaan alat } \\
\text { tulis, serta jika terjadi } \\
\text { kehilangan laporan } \\
\text { penggajin maka data } \\
\text { masih tersimpan di } \\
\text { sistem }\end{array}$ \\
\hline
\end{tabular}

\section{c. Perancangan Usulan Sistem Informasi}

Sistem yang diusulkan oleh penulis adalah sitem informasi penggajian pegawai berbasis web dengan menggunakan PHP dan MySQL. Rancangan sistem yang dibuat adalah:

1. Use Case Diagram

Use case diagram merupakan gambaran fungsional secara umum dari suatu sistem yang dikembangkan, sehingga mudah untuk dimengerti kegunaan dari sistem yang akan dibangun. Untuk merancang sistem penggajian yang akan dikembangkan dibuat Use case diagram yang ditunjukkan pada Gambar 2. 


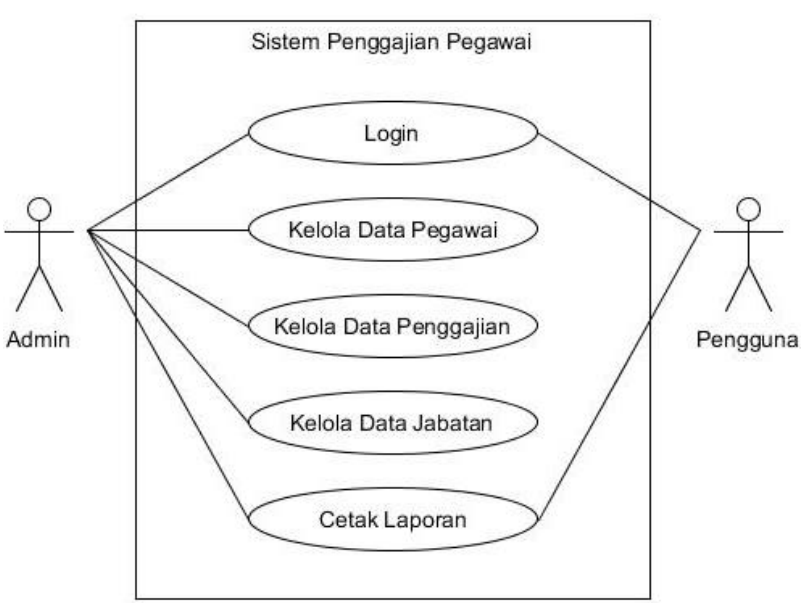

Gambar 2 Use Case Diagram Login

Use case tersebut menjelaskan adanya 2 pengguna, yaitu Admin yang bisa melakukan kelola data jabatan, data pegawai, data penggajian dan laporan. Sedangkan pengguna yang kedua terdiri dari pegawai dan kepala sekolah. Pegawai ataupun kepala sekolah bisa melakukan lihat laporan dan sekaligus mencetak laporan sesuai dengan hak akses masing-masing.

\section{Class Diagram}

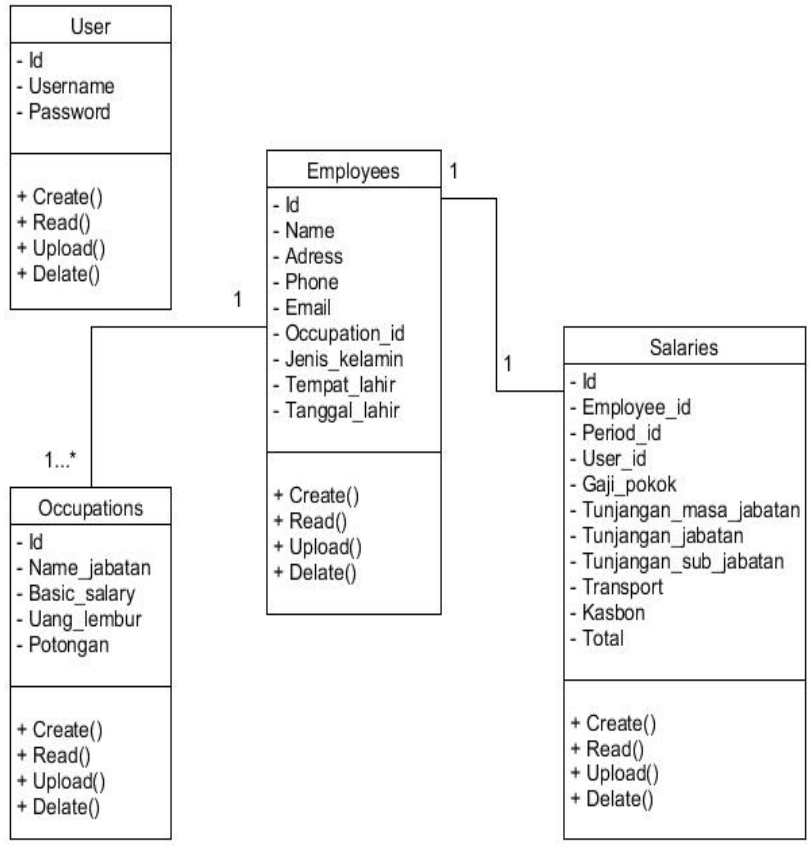

Gambar 3 Class Diagram

Clas diagram tersebut menggambarkan 4 clas yang terdapat dalam aplikasi ini yaitu User, Occupation, Employees dan Saleries.

\section{d. Implementasi}

Pada tahap implementasi dibuat source code berdasarkan rancangan yang telah dibuat. Hasil implementasinya antara lain:

1. Login

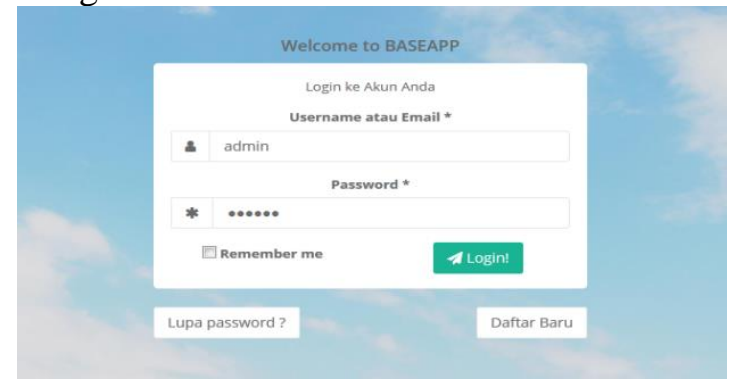

Gambar 4 Implementasi menu login

Tampilan pada gambar 4 login menjelaskan login buat user, untuk pembagian login terdapat 4 user yang terdiri Admin, Pegawai dan Kepala Sekolah.

2. Data Jabatan

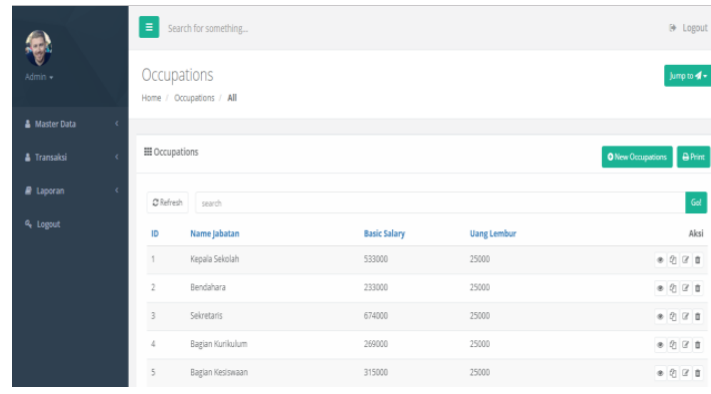

Gambar 5 Implementasi menu data jabatan

Gambar 5 data jabatan menjelaskan bagaimana implementasi untuk melakukan input jabatan yang di dalamnya termasuk juga gaji pokok (basic salary) dan uang lembur yang didapatkan.

3. Data Pegawai

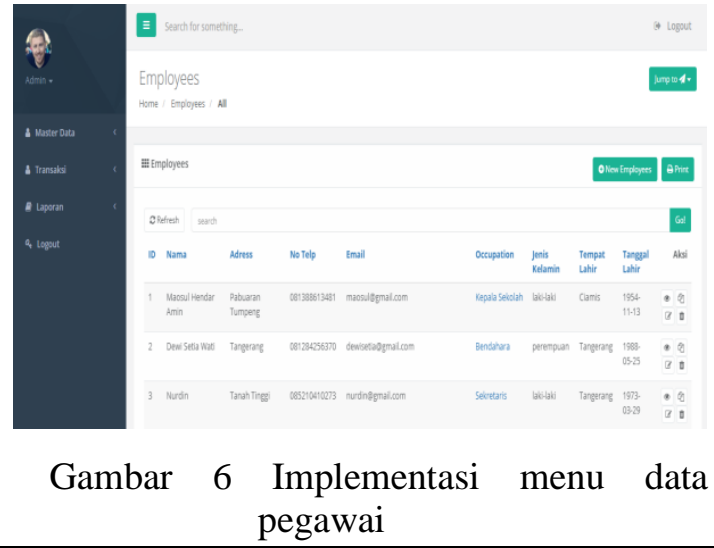
pegawai 
Gambar 6 data pegawai menjelaskan input data pegawai yang terdiri dari field Id, Nama, Adress, No Telp, Email, Uccupation, Jenis Kelamin, Tempat Lahir, dan Tanggal Lahir.

\section{List Gaji}

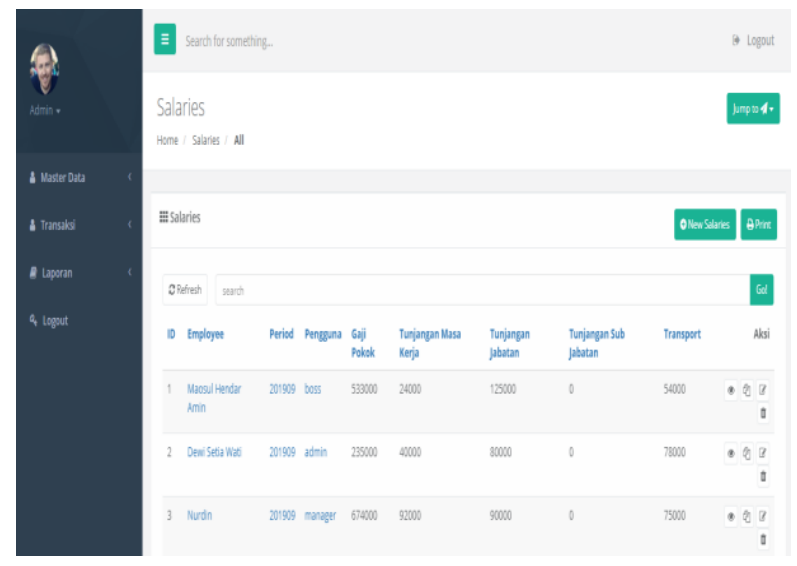

Gambar 7 Implementasi menu list gaji

Gambar 7 merupakan implementasi list gaji, dalam tampilan ini dapat digunakan untuk melakukan input yang bisa dilakukan terdiri id, Employee (pegawai), Period, Pengguna, Gaji Pokok, Tunjangan Masa Kerja, Tunjangan Jabatan dan Transport.

\section{Report (Slip)}

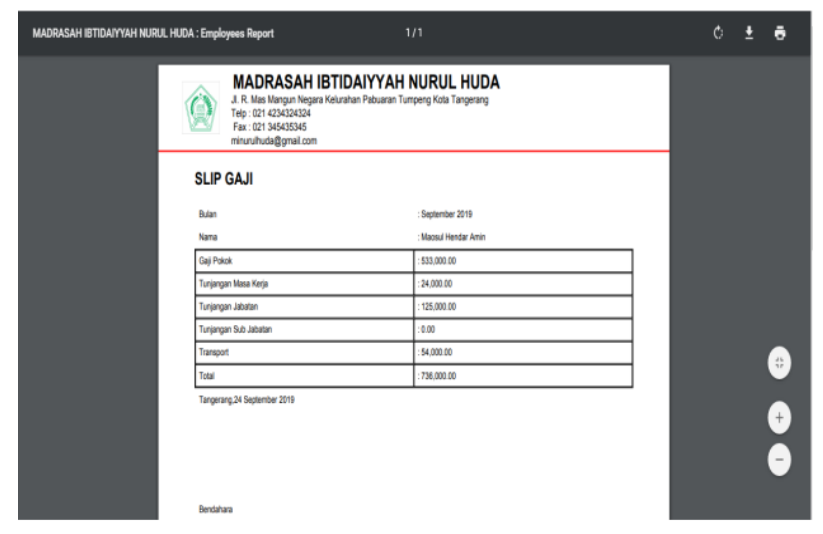

Gambar 8 Implementasi report (slip)

Gambar 8 report ini menjelaskan laporan slip gaji yang akan diterima oleh masing-masing pegawai, termasuk kepala sekolah sampai ke staff. Dengan sistem ini pegawai bisa melihat berapa pendapatan per bulan yang akan didapatkan.

\section{e. Testing}

Setiap program perlu menjalani pengujian secara pribadi untuk menjamin kualitasnya dan memastikan bahwa program yang dikembangkan bebas dari kesalahan (bug). Walaupun setelah dilakukan pengujian tidak menutup kemungkinan masih mengandung sedikit bug dengan kata lain tidak $100 \%$ bebas dari bug. Tetapi pengujian harus dilakukan untuk meminimalisasi kesalahan yang mungkin akan terjadi.

Pengujian secara black box merupakan suatu pendekatan pengujian untuk memverivikasi dan memvalidasi apakah semua fungsi yang dibutuhkan sudah ada dalam sistem dan dapat berjalan dengan benar. Hasil pengujian secara black box dari aplikasi sistem penggajian pegawai pada MI. Nurul Huda Kota Tangerang ditunjukkan pada Tabel 2.

Tabel 2 Hasil pengujian dengan pendekatan black-box

\begin{tabular}{|c|c|c|c|}
\hline No & Uii Coba & Proses & Hasil \\
\hline 1 & Form Login & $\begin{array}{l}\text { Input username } \\
\text { dan password }\end{array}$ & Berhasil \\
\hline 2 & Menu Utama & $\begin{array}{l}\text { Tampil jika login } \\
\text { sukses }\end{array}$ & Berhasil \\
\hline 3 & $\begin{array}{l}\text { Form kelola } \\
\text { data user }\end{array}$ & $\begin{array}{l}\text { Input data dan } \\
\text { simpan }\end{array}$ & Berhasil \\
\hline 4 & $\begin{array}{l}\text { Form kelola } \\
\text { data jabatan }\end{array}$ & $\begin{array}{l}\text { Input data dan } \\
\text { simpan }\end{array}$ & Berhasil \\
\hline 5 & $\begin{array}{l}\text { Form kelola } \\
\text { data pegawai }\end{array}$ & $\begin{array}{l}\text { Input data dan } \\
\text { simpan }\end{array}$ & Berhasil \\
\hline 6 & $\begin{array}{l}\text { Form kelola } \\
\text { data } \\
\text { penggajian }\end{array}$ & $\begin{array}{l}\text { Input data dan } \\
\text { simpan }\end{array}$ & Berhasil \\
\hline 7 & $\begin{array}{l}\text { Form kelola } \\
\text { data laporan }\end{array}$ & \begin{tabular}{|l|}
$\begin{array}{l}\text { Input data dan } \\
\text { simpan }\end{array}$ \\
\end{tabular} & Berhasil \\
\hline 8 & Logout & Klik logout & Berhasil \\
\hline
\end{tabular}

\section{Kesimpulan}

Dalam penelitian ini telah diuraikan bagaimana perancangan sistem Penggajian Pegawai pada MI. Nurul Huda Kota Tangerang, maka dapat kami simpulkan sebagai berikut:

1. Dengan adanya rancangan sistem informasi yang tepat terutama dalam mengatasi masalah sebelumnya yaitu perhitungan gaji pegawai secara manual.

2. Dengan adanya rancangan sistem informasi yang tepat terutama dalam mengatasi masalah perhitungan lembur maupun potongan gaji.

3. Pembuatan laporan menjadi lebih cepat dan mudah karena hasil input bisa diubah ke dalam file pdf dan dicetak (print) dalam bentuk hardcopy. 


\section{Referensi}

Darmawan, Deni dan Fauzi, Nur, Kunkun. 2013. Sistem Informasi Manajemen. Bandung: PT Remaja Rosdakarya.

Indrajani. 2014. “Database System”. Jakarta: PT. Elex Media Komputindo.

Moch. Tofik. 2010 Panduan Praktisi Membuat Apliukasi Penggajian Dengan Excel 2007, Jakarta: Penerbit Mediakita,

Nugroho, Adi. 2010. "Rekayasa Perangkat Lunak Menggunakan UML \& Java”. Yogyakarta: Andi Offiset.

Robbins, P. Stephen. 2006. Perilaku Organisasi. Edisi Sepuluh. Diterjemahkan oleh: Drs. Benyamin Molan. Erlangga, Jakarta.

Salidi Samsudin. 2010. Manajemen Sumber Daya Manusia. Bandung Penerbit Pustaka Setia

Taufiq, Rohmat. 2013. "Sistem Informasi Manajemen; Konsep Dasar, Analisis dan Metode Pengembangan". Yogyakarta: Graha Ilmu.

Taufiq, R, 2018, Pengantar Sistem Informasi, Mitra Wacana Media. Jakarta. 